Article

\title{
Chemical Composition and Antioxidant Activity of Essential Oils from Cinnamodendron dinisii Schwacke and Siparuna guianensis Aublet
}

Milene Aparecida Andrade ${ }^{1}$, Maria das Graças Cardoso ${ }^{1{ }^{*},}$, Juliana de Andrade ${ }^{1}$, Lucilene Fernandes Silva ${ }^{1}$, Maria Luisa Teixeira ${ }^{1}$, Juliana Maria Valério Resende ${ }^{2}$, Ana Cristina da Silva Figueiredo ${ }^{3}$ and José Gonçalves Barroso ${ }^{3}$

1 Department of Chemistry, University of Lavras, Lavras, MG 37200-000, Brazil; E-Mails: mileneaandrade@hotmail.com (M.A.A.); juandrade_quimica@yahoo.com.br (J.A.); lufernandes1000@hotmail.com (L.F.S.); teixeira_ml@hotmail.com (M.L.T.)

2 Department of Food Science, University of Lavras, Lavras, MG 37200-000, Brazil; E-Mail: jumvalerio82@hotmail.com

3 Universidade de Lisboa, Faculdade de Ciências de Lisboa, DBV, Instituto de Biotecnologia e Bioengenharia, Centro de Biotecnologia Vegetal, C2, Campo Grande, 1749-016 Lisboa, Portugal; E-Mails: acsf@fc.ul.pt (A.C.S.F.); jgbarroso@fc.ul.pt (J.G.B.)

* Author to whom correspondence should be addressed; E-Mail: mcardoso@dqi.ufla.br; Tel.: +55-35-3829-1202; Fax: +55-35-3829-1271.

Received: 31 August 2013; in revised form: 8 October 2013 / Accepted: 28 October 2013 / Published: 26 November 2013

\begin{abstract}
The objectives of this study were to chemically characterize and evaluate the antioxidant activity of essential oils Cinnamodendron dinisii Schwacke (pepper) and Siparuna guianensis Aublet (negramina). The essential oil was isolated by hydrodistillation using a Clevenger modified apparatus, and the identification and quantification of constituents, through GC/MS and GC-FID analysis. The antioxidant activity was evaluated using $\beta$-carotene/linoleic acid system and the DPPH radical sequestering method. In chromatographic analysis, the majority constituents found in the essential oil of $C$. dinisii were bicyclic monoterpenes, $\alpha$-pinene $(35.41 \%), \beta$-pinene $(17.81 \%)$, sabinene $(12.01 \%)$ and sesquiterpene bicyclogermacrene (7.59\%). In the essential oil of the fresh leaves of Siparuna guianensis Aublet, acyclic monoterpene, $\beta$-myrcene (13.14\%), and sesquiterpenes, germacrene-D (8.68\%) and bicyclogermacrene $(16.71 \%)$ were identified. The antioxidant activity was low by the $\beta$-carotene/linoleic acid test and was not evidenced by the DPPH test, for both oils evaluated.
\end{abstract}


Keywords: volatile oils; chemical composition; free radicals

\section{Introduction}

The use of medicinal plants by humans dates back thousands of years due to their medicinal and nutritional properties. Many natural compounds extracted from plants have important biological activities. Among these compounds, we highlight the essential oils, which are increasingly attracting the attention of various segments of industry due to their multiple functions, especially antioxidant and antimicrobial activities.

Essential oils are defined by ISO as the products obtained from different parts of plants through distillation by steam distillation, hydro distillation and pressing the citrus fruit pericarp techniques. They are complex mixtures of volatile and lipophilic substances, formed by the secondary metabolism of plants characterized by a pleasant odor most of them presented [1,2].

Essential oils are marketed by various companies as raw material for various products with applications in perfumery, cosmetics, foods, and as adjuncts in medicines, among others. There are approximately 300 essential oils of commercial importance in the world. In the food industry, essential oils, besides imparting aroma and flavor to food, have important antioxidant activity, a property that further encourages its use [3].

In foods, lipid peroxidation is responsible for the development of unpleasant flavors and odors, making them unfit for consumption, and causes other changes that may affect the nutritional quality due to degradation of fat soluble vitamins and essential fatty acids, as well affecting the integrity and safety of food. In biological systems, lipid peroxidation on cell membrane unsaturated lipids causes membrane damage, disrupting the metabolite exchange mechanisms, and may cause cell death, becoming largely responsible for early aging and cardiovascular disease, cataracts, immune system decline and brain dysfunction, among others [4,5].

To prevent lipid peroxidation of foods, synthetic antioxidants commonly used in the industry are BHA, BHT, TBHQ and PG. However, studies assessing the toxicology of these compounds have demonstrated their carcinogenic potential in animals. Given the evidence of problems that can be caused by the consumption of synthetic antioxidants, research has emerged with the goal of finding natural products with antioxidant potential, which are an alternative to substitute the synthetic compounds or even promote an association between them, order to reduce their amount in food. One advantage of natural antioxidants versus the synthetic is that legislation regarding them is more flexible, but the natural antioxidants, in most cases, have lower antioxidant capacities than those of synthetic compounds $[4,6]$.

The antioxidant activity of volatile oils, even very pronounced, can hardly be attributed to the components alone since due to the complex chemical composition of these natural compounds, which may contain molecules with different functional groups, the magnitude of the antioxidant activity shown by them can be related to the effect caused by the interaction of all constituents present in the essential oil, from those present in a greater proportion to those present in minor amounts. This interaction may produce a synergistic effect, when the interaction enhances the effect of the oil, or 
antagonistic, when the interaction negatively affects the antioxidant activity of the oil in study, which makes it very important to investigate the antioxidant properties of essential oils without considering only its major components [7].

The Cinnamodendron dinisii Schwacke species is a tree, 10-20 feet high, of the family Canellaceae, commonly known as "pepper" or "cure-all", because the bark of the trunk, with a spicy flavor like true pepper, possesses medicinal properties and is slightly numbing $[8,9]$.

The species Siparuna guianensis Aublet is used as a medical resource medicinal among the population of Mato Grosso, where the decoction of its leaves is used to combat sinusitis symptoms, fever, rheumatism, migraine, flu, body aches and "malina". It is popularly known as "negramina" and belongs to the family Siparunaceae [10].

Given the growing importance of essential oils in the world market, their biological potential and existing species diversity as yet unexplored, further studies are needed that make their use viable. The objectives of this study were to chemically characterize and evaluate the antioxidant activity of essential oils of $C$. dinisii and S. guianensis.

\section{Experimental Section}

\subsection{Plant Material}

Leaves Cinnamodendron dinisii and Siparuna guianensis were collected in February 2011, in the morning, in the Medicinal Plant Garden of UFLA and on the UFLA campus respectively. The $C$. dinisii collection site has the following coordinates: $-21^{\circ} 13^{\prime} 49.0476^{\prime \prime}$ latitude, $-44^{\circ} 58^{\prime} 27.4764^{\prime \prime}$ longitude and $933 \mathrm{~m}$ of altitude, and the $S$. guianensis collection site: $-21^{\circ} 13^{\prime} 41.9952^{\prime \prime}$ latitude, $-44^{\circ} 58^{\prime} 9.0048^{\prime \prime}$ longitude and $951 \mathrm{~m}$ of altitude.

The species were duly identified and a voucher specimen of each species is registered in with the ESAL Herbarium, located in the Biology Department of UFLA, with the following registration numbers: 26,285 (Cinnamodendron dinisii Schwacke) and 26,623 (Siparuna guianensis Aublet).

The collected material was sent to the Laboratory of Organic Chemistry-Essential Oils of the Chemistry Department, Federal University of Lavras (UFLA) Lavras/MG, in which mature healthy leaves were selected with no injuries and blemishes caused by pathogens, insects or sunburn. The plant material was properly packaged and maintained under refrigeration $\left(\approx 7^{\circ} \mathrm{C}\right)$ until extraction of essential oils.

\subsection{Essential Oil Extraction}

The essential oil extractions were carried out in the Laboratory of Organic Chemistry-Essential Oils, Federal University of Lavras. The extraction method was hydro distillation using a modified Clevenger apparatus [11].

Three repetitions of the extraction from each plant were conducted using $300 \mathrm{~g}$ of fresh, chopped leaves for each repetition, distilling for $2 \mathrm{~h}$. After this time, the oil was separated from the hydrolyte by centrifugation at $1100 \mathrm{~g}$ for $5 \mathrm{~min}$, using a bench top centrifuge with horizontal crosspiece (Fanem Baby ${ }^{\circledR}$ I Model 206 BL). The oil was removed with the aid of a Pasteur pipette, placed in a glass bottle, stored under refrigeration $\left(4^{\circ} \mathrm{C}\right)$, and protected from light [12]. 


\subsection{Identification and Quantification of the Essential Oil Constituents}

The identification of the constituents of the essential oils was performed by gas-liquid chromatography coupled to mass spectrometry (GC-MS), using an Autosystem XL equipped with a DB-1 fused silica column $(30 \mathrm{~m} \times 0.25 \mathrm{~mm}$ ID, film thickness $0.25 \mathrm{~m}$; J \& W Scientific Inc., Rancho Cordova, CA, USA) connected to a Perkin-Elmer Turbomass. The oven temperature was programmed from 45 to $175{ }^{\circ} \mathrm{C}$ in increments of $3{ }^{\circ} \mathrm{C} / \mathrm{min}$ and subsequently at $15{ }^{\circ} \mathrm{C} / \mathrm{min}$ to $300{ }^{\circ} \mathrm{C}$. On reaching $300{ }^{\circ} \mathrm{C}$, the temperature was kept isothermal for $10 \mathrm{~min}$, temperature of the transfer line, $280{ }^{\circ} \mathrm{C}$; temperature of the ionization chamber $220{ }^{\circ} \mathrm{C}$, helium carrier gas, adjusted to a linear velocity of $30 \mathrm{~cm} / \mathrm{s}$; split-flow ratio 1:40, ionization energy $70 \mathrm{eV}$, ionization current, $60 \mu \mathrm{A}$; mass range, 40-300 u (atomic mass unit), scan time $1 \mathrm{~s}$. The compounds were identified by comparison of their retention indices, relative to those of $n$-alkanes $\mathrm{C}_{9}-\mathrm{C}_{21}$ and by comparison with a library of mass spectra developed in the laboratory of the Centre for Plant Biotechnology, Faculdade de Ciências da Universidade de Lisboa-Portugal [13].

The content of each constituent was determined by gas chromatography (GC-FID) in a Perkin Elmer 8700 gas chromatograph equipped with two Flame Ionization Detectors (FID), a data processing system and an injector, in which two columns of different polarity were installed: DB-1 fused silica, with immobilized methyl silicone phase $(30 \mathrm{~m} \times 0.25 \mathrm{~mm}$ ID, film thickness $0.25 \mathrm{~m}$; J \& W Scientific Inc.) and DB-17HT fused silica (30 m $\times 0.25 \mathrm{~mm}$ ID, film thickness $0.25 \mathrm{~mm}$; J \& W Scientific Inc.). The oven temperature was programmed from $45{ }^{\circ} \mathrm{C}$ to $175{ }^{\circ} \mathrm{C}$ in increments of $3{ }^{\circ} \mathrm{C} / \mathrm{min}$ and subsequently at $15{ }^{\circ} \mathrm{C} / \mathrm{min}$ to $300{ }^{\circ} \mathrm{C}$. On reaching $300{ }^{\circ} \mathrm{C}$, the temperature was kept isothermal for $10 \mathrm{~min}$. Injector and detector temperature, $290{ }^{\circ} \mathrm{C}$ and $280{ }^{\circ} \mathrm{C}$, respectively. Hydrogen was used as carrier gas adjusted to a linear velocity of $30 \mathrm{~cm} / \mathrm{s}$. Split-flow ratio of 1:50. The percentage of oil constituents was determined by integration of peak areas without using correction factors. The values shown correspond to the average value of two injections [13].

\subsection{Determination of Antioxidant Activity}

\subsubsection{Reducing Method of Stable Radical DPPH}

A DPPH methanolic solution was prepared at a concentration of $40 \mu \mathrm{g} \mathrm{mL}^{-1}$. For the evaluation, $2.7 \mathrm{~mL}$ of the stock DPPH solution were added in a test tube, followed by the addition of $0.3 \mathrm{~mL}$ of each dilution of the oil in methanol $\left(300,250,200,150,100,50 ; 25 \mathrm{~g} \mathrm{~mL}^{-1}\right)$. In parallel, the control was prepared containing all reagents except the essential oil. After $60 \mathrm{~min}$, readings were taken using a spectrophotometer (Shimadzu UV-160 1PC) at a wavelength of $517 \mathrm{~nm}$ [14].

The antioxidant activity was calculated as percentage inhibition of DPPH, using the following equation:

$$
\% I=100-(\mathrm{DPPHs} / \mathrm{DPPHw} / \mathrm{s}) / 100
$$

where $\% I$ is the inhibition percentage of the DPPH radical, DPPHs corresponds to the absorbance of DPPH with the sample and DPPHw/s the absorbance of DPPH without sample (blank).

For comparison, activities of BHT, ascorbic acid and thymol standards were evaluated. 


\subsubsection{Assay of $\beta$-Carotene/Linoleic Acid Oxidation System}

In a round bottom flask, $60 \mu \mathrm{L}$ of linoleic acid, $600 \mathrm{mg}$ of Tween $20,6 \mathrm{mg}$ of $\beta$-carotene and $30 \mathrm{~mL}$ of chloroform were added. All the chloroform was removed using a rotary evaporator with a water bath at $50{ }^{\circ} \mathrm{C}$ (Büchi Rotavapor R 114). Subsequently, the residue was dissolved in $150 \mathrm{~mL}$ of distilled water saturated with oxygen under vigorous stirring. In test tubes, $2.7 \mathrm{~mL}$ of this solution were added to 0.3 $\mathrm{mL}$ of each oil $(300,250,200,150,100,50,25 \mu \mathrm{g} / \mathrm{mL})$, the control comprised only of methanol. The absorbance was measured immediately in a spectrophotometer (Shimadzu UV-160 1PC) at $470 \mathrm{~nm}$ [15].

After reading the initial absorbance, the tubes were incubated in a water bath at $50{ }^{\circ} \mathrm{C}$ for the oxidation reaction, a second reading being conducted after 60 min of incubation. All readings were performed in triplicate.

According to Wang et al. [16] the antioxidant activity was expressed as percentage of inhibition after 60 min of incubation using the following equation:

$$
\% \mathrm{AA}=100 \times(\mathrm{Drc}-\mathrm{Drs}) / \mathrm{Drc}
$$

where $\% \mathrm{AA}$ is the inhibition percentage of $\beta$-carotene degradation, Drc is the degradation ratio of the control $[(\ln (a / b) / 60]$, Drs the degradation ratio in the presence of the sample $[(\ln (a / b) / 60]$, " $a$ " corresponds to absorbance at time zero and " $b$ " corresponds to absorbance at $60 \mathrm{~min}$.

For comparison, activities of BHT, ascorbic acid and thymol standards were evaluated.

\subsubsection{Statistical Analysis}

For both tests, a completely randomized design (CRD) was used with seven concentrations and three replicates for each sample (or standard). The SISVAR [17] statistical program was used. Data were subjected to analysis of variance and the averages obtained were subjected to regression to $5 \%$ probability.

The adjusted equations were used to calculate the $\mathrm{IC}_{50}$ and graphs were plotted with the $\% I$ values of the DPPH assay, or \%AA for the $\beta$-carotene/linoleic acid system versus the concentrations analyzed using the software Origin 6.0.

\section{Results and Discussion}

\subsection{Identification and Quantification of the Constituents of Essential Oils}

We identified 39 constituents present in the essential oil of $C$. dinisii, which are shown in Table 1. It can be observed that the essential oil presents almost entirely monoterpene hydrocarbons (76.20\%), presenting as majority components bicyclic monoterpenes, $\alpha$-pinene (35.41\%), $\beta$-pinene (17.81\%), sabinene (12.01\%) and sesquiterpene bicyclogermacrene $(7.59 \%)$. We noted the presence of a drimane-type sesquiterpene, drimenol $(0.20 \%)$, present in the composition of many species of Canellaceae.

In the essential oil of the fresh leaves of S. guianensis, 41 constituents were identified (Table 1), which are composed mainly of sesquiterpene hydrocarbons (41.50\%), oxygenated sesquiterpenes $(19.40 \%)$ and monoterpene hydrocarbons (17.90\%), respectively. As majority compounds, acyclic monoterpene, $\beta$-myrcene (13.14\%) and sesquiterpenes germacrene-D (8.68\%) and bicyclogermacrene (16.71\%) were identified. 
Table 1. Chemical composition of the essential oil of fresh leaves of Cinnamodendron dinisii and Siparuna guianensis.

\begin{tabular}{|c|c|c|c|}
\hline \multirow[b]{2}{*}{ RIc * } & \multirow[b]{2}{*}{ Compound } & \multicolumn{2}{|c|}{$\% \mathbf{I} * *$} \\
\hline & & C. dinisii & S. guianensis \\
\hline 921 & Tricyclene & $\mathrm{t} * * *$ & $\mathrm{t}$ \\
\hline 924 & $\alpha$-Thujene & 1.06 & $\mathrm{t}$ \\
\hline 930 & $\alpha$-Pinene & 35.41 & 1.83 \\
\hline 938 & Camphene & 0.71 & 0.04 \\
\hline 958 & Sabinene & 12.01 & $\mathrm{t}$ \\
\hline 963 & $\beta$-Pinene & 17.81 & 0.86 \\
\hline 975 & $\beta$-Myrcene & 1.46 & 13.14 \\
\hline 995 & $\alpha$-Phellandrene & $\mathrm{t}$ & 0.03 \\
\hline 1000 & $\delta$-3-Carene & - & 0.72 \\
\hline 1002 & $\alpha$-Terpinene & 0.24 & - \\
\hline 1003 & $p$-Cymene & 1.21 & $\mathrm{t}$ \\
\hline 1004 & 1,8-Cineole & 4.37 & - \\
\hline 1009 & Limonene & 1.54 & 1.23 \\
\hline 1005 & $\beta$-Phellandrene & $\mathrm{t}$ & 0.06 \\
\hline 1017 & cis- $\beta$-Ocimene & 1.99 & 0.03 \\
\hline 1027 & trans- $\beta$-Ocimene & 1.82 & $\mathrm{t}$ \\
\hline 1035 & $\gamma$-Terpinene & 0.75 & - \\
\hline 1037 & trans-Sabinene hydrate & 0.15 & - \\
\hline 1064 & Terpinolene & 0.17 & $\mathrm{t}$ \\
\hline 1066 & cis-Sabinene hydrate & 0.15 & - \\
\hline 1074 & Linalool & 0.65 & - \\
\hline 1098 & $\alpha$-Campholenal & $\mathrm{t}$ & \\
\hline 1099 & trans-p-2-Menthen-1-ol & 0.09 & - \\
\hline 1106 & trans-Pinocarveol & 0.11 & - \\
\hline 1110 & allo-Ocimene & 0.03 & - \\
\hline 1110 & cis-p-2-Menthen-1-ol & $\mathrm{t}$ & \\
\hline 1114 & trans-Verbenol & 0.03 & - \\
\hline 1121 & Pinocarvone & $\mathrm{t}$ & \\
\hline 1134 & Borneol & 0.36 & - \\
\hline 1148 & Terpinen-4-ol & 2.50 & - \\
\hline 1153 & Myrtenal & $\mathrm{t}$ & \\
\hline 1159 & $\alpha$-Terpineol & 0.11 & - \\
\hline 1168 & Myrtenol & 0.05 & - \\
\hline 1265 & Bornyl Acetate & 0.10 & $\mathrm{t}$ \\
\hline 1275 & 2-Undecanone & - & 1.69 \\
\hline 1332 & $\delta$-Elemene & 0.32 & 0.58 \\
\hline 1334 & $\alpha$-Terpinyl Acetate & 0.32 & - \\
\hline 1345 & $\alpha$-Cubene & - & 0.04 \\
\hline 1375 & $\alpha$-copaene & 0.11 & 0.27 \\
\hline 1379 & $\beta$-Bourbonene & - & 0.31 \\
\hline 1388 & $\beta$-Elemene & 0.21 & 2.08 \\
\hline
\end{tabular}


Table 1. Cont.

\begin{tabular}{|c|c|c|c|}
\hline 1385 & $\beta$-Cubebene & - & 0.18 \\
\hline 1400 & $\alpha$-Gurjunene & - & $\mathrm{t}$ \\
\hline 1414 & $\beta$-Caryophyllene & 1.88 & 1.12 \\
\hline 1426 & $\gamma$-Elemene & - & 0.05 \\
\hline 1428 & $\beta$-Copaene & - & 0.04 \\
\hline 1428 & Aromandrene & 0.23 & 0.04 \\
\hline 1447 & $\alpha$-Humulene & $\mathrm{t}$ & 2.07 \\
\hline 1456 & allo-Aromadendrene & - & 0.05 \\
\hline 1455 & trans- $\beta$-Farnesene & 0.20 & - \\
\hline 1469 & trans-Cadina-1(6)-4-diene & - & $\mathrm{t}$ \\
\hline 1474 & Germacrene-D & - & 8.68 \\
\hline 1476 & $\beta$-Selinene & $\mathrm{t}$ & 0.20 \\
\hline 1487 & Bicyclogermacrene & 7.59 & 16.71 \\
\hline- & Curzerene & - & 2.15 \\
\hline 1493 & $\gamma$-Muurolene & - & $\mathrm{t}$ \\
\hline 1494 & $\alpha$-Muurolene & - & 1.17 \\
\hline 1500 & (trans,trans) $\alpha$-Farnesene & 0.09 & - \\
\hline 1500 & $\gamma$-Cadinene & - & 2.13 \\
\hline 1505 & trans-Calamene & - & 0.29 \\
\hline 1505 & $\delta$-Cadinene & 0.14 & 1.04 \\
\hline 1549 & trans-Nerolidol & 0.05 & - \\
\hline 1533 & Germacrene-B & - & 2.34 \\
\hline 1551 & Spathulenol & 1.88 & 4.16 \\
\hline 1561 & $\beta$-Caryophyllene Oxide & 0.42 & 0.45 \\
\hline 1566 & Globulol & 0.32 & 0.40 \\
\hline 1569 & Viridiflorol & 0.16 & 3.00 \\
\hline- & Humulene epoxide II & - & 0.63 \\
\hline 1600 & 1-epi-Cubenol & - & 0.15 \\
\hline 1616 & T-Cadinol & - & 4.14 \\
\hline 1620 & $\beta$-Eudesmol & - & 1.02 \\
\hline 1626 & $\alpha$-Cadinol & - & 1.95 \\
\hline 1656 & $\alpha$-Bisabolol & - & 3.53 \\
\hline 1764 & Drimenol & 0.20 & - \\
\hline- & Atractylone & - & $\mathrm{t}$ \\
\hline \multicolumn{2}{|r|}{ Total identified (\%) } & 99.00 & 80.48 \\
\hline \multicolumn{2}{|r|}{ Monoterpene hydrocarbons } & 76.20 & 17.90 \\
\hline \multicolumn{2}{|r|}{ Oxygenated monoterpenes } & 9.00 & 0.00 \\
\hline \multicolumn{2}{|r|}{ sesquiterpene hydrocarbons } & 10.80 & 41.50 \\
\hline \multicolumn{2}{|r|}{ Oxygenated sesquiterpenes } & 3.00 & 19.40 \\
\hline \multicolumn{2}{|r|}{ Others } & 1.00 & 1.70 \\
\hline
\end{tabular}

$* \mathrm{RIc}=$ retention index calculated; $* * \%=$ concentration in percentage; $* * * \mathrm{t}=$ traces.

Some research was carried out to evaluate the chemical composition of essential oils obtained from different plant parts of the same species (or species belonging to the same family) evaluated in this study, as can be seen in Table 2 . 
Table 2. Chemical composition of the essential oils obtained from different plant parts of species of the Canellaceae family and of the Siparuna guianensis specie found by others authors.

\begin{tabular}{|c|c|c|c|c|}
\hline Authors & Plant & $\begin{array}{c}\text { Part of } \\
\text { plant used }\end{array}$ & Place & $\begin{array}{c}\text { Chemical composition } \\
\text { (main compounds) }\end{array}$ \\
\hline $\begin{array}{c}\text { Torres } \\
\text { et al. }[18]\end{array}$ & $\begin{array}{c}\text { Capsicodendron } \\
\text { dinisii } \\
\end{array}$ & Bark & $\begin{array}{l}\text { Guarapuava } \\
\text { (PR)_-Brazil }\end{array}$ & Monoterpenes-( $68.5 \%$ of limonene). \\
\hline $\begin{array}{l}\text { Adams } \\
\text { and } \\
\text { Zanoni } \\
{[19]}\end{array}$ & $\begin{array}{c}\text { Cinnamodendron } \\
\text { ekamani }\end{array}$ & Wood & $\begin{array}{l}\text { Hispaniola- } \\
\text { Caribbean } \\
\text { island }\end{array}$ & $\begin{array}{c}\text { 1,8-cineole, } \alpha \text {-humulene, } \beta \text {-caryophyllene, } \\
\text { 4-terpineol, germacrene- } \mathrm{D}, \beta \text {-elemene, } \\
\alpha \text {-pinene and } \alpha \text {-terpineol. }\end{array}$ \\
\hline $\begin{array}{l}\text { Tucker } \\
\text { et al. }[20]\end{array}$ & $\begin{array}{l}\text { Cinnamosma } \\
\text { fragrans }\end{array}$ & $\begin{array}{l}\text { Commercial } \\
\text { essential oil }\end{array}$ & Madagascar & 1,8-cineole and sabinene. \\
\hline Setzer [21] & Canella winterana & Leaves & $\begin{array}{l}\text { Islands of } \\
\text { Abaco- } \\
\text { Bahamas }\end{array}$ & $\begin{array}{l}\text { Myrcene, } \beta \text {-caryophyllene, } \\
\text { cis- and trans- } \beta \text {-ocimene. }\end{array}$ \\
\hline $\begin{array}{l}\text { Amiguet } \\
\text { et al. [22] }\end{array}$ & $\begin{array}{l}\text { Pleodendron } \\
\text { costaricense }\end{array}$ & $\begin{array}{c}\text { Leaves and } \\
\text { bark }\end{array}$ & $\begin{array}{c}\text { Parrita (Costa } \\
\text { Rica) }\end{array}$ & $\begin{array}{l}\beta \text {-pinene, } \alpha \text {-pinene, } \beta \text {-myrcene, } \beta \text {-thujene } \\
\text { and } \beta \text {-caryophyllene. }\end{array}$ \\
\hline $\begin{array}{l}\text { Valentini } \\
\text { et al. }[23]\end{array}$ & $\begin{array}{l}\text { Siparuna } \\
\text { guianensis }\end{array}$ & Leaves & $\begin{array}{l}\text { Cerrado in } \\
\text { Mato } \\
\text { Grosso- } \\
\text { Brazil }\end{array}$ & $\begin{array}{l}\text { Sesquiterpenes and sesquiterpene } \\
\text { hydrocarbon. }\end{array}$ \\
\hline $\begin{array}{l}\text { Antônio } \\
\text { et al. [24] }\end{array}$ & $\begin{array}{l}\text { Siparuna } \\
\text { guianensis }\end{array}$ & Leaves & Panama & $\begin{array}{l}\text { Curzerene, derivatives their degradation and } \\
\text { myristicin. }\end{array}$ \\
\hline $\begin{array}{c}\text { Rebouças } \\
{[25]}\end{array}$ & $\begin{array}{l}\text { Siparuna } \\
\text { guianensis }\end{array}$ & Leaves & $\begin{array}{l}\text { Rio Branco } \\
\text { (AC)-Brazil }\end{array}$ & $\begin{array}{c}\gamma \text {-cadinene, bergamotene and } \\
\beta \text {-caryophyllene. }\end{array}$ \\
\hline $\begin{array}{c}\text { Montanari } \\
{[26]}\end{array}$ & $\begin{array}{l}\text { Siparuna } \\
\text { guianensis }\end{array}$ & Leaves & $\begin{array}{l}\text { Tocantins } \\
(\mathrm{MG}) \text {-Brazil }\end{array}$ & $\alpha$-terpinolene and $\alpha$-bisabolol. \\
\hline $\begin{array}{l}\text { Fischer } \\
\text { et al. [27] }\end{array}$ & $\begin{array}{l}\text { Siparuna } \\
\text { guianensis }\end{array}$ & $\begin{array}{l}\text { Leaves and } \\
\text { fruits }\end{array}$ & $\begin{array}{l}\text { Brazilian } \\
\text { cerrado }\end{array}$ & $\begin{array}{l}\text { Leaves: decanoic acid and 2-undecanone. } \\
\text { Fruit: undecanone-2, } \beta \text {-pinene and limonene. }\end{array}$ \\
\hline $\begin{array}{l}\text { Zoghbi } \\
\text { et al. }[28]\end{array}$ & $\begin{array}{l}\text { Siparuna } \\
\text { guianensis }\end{array}$ & Leaves & $\begin{array}{l}\text { Different } \\
\text { places of the } \\
\text { Amazon }\end{array}$ & 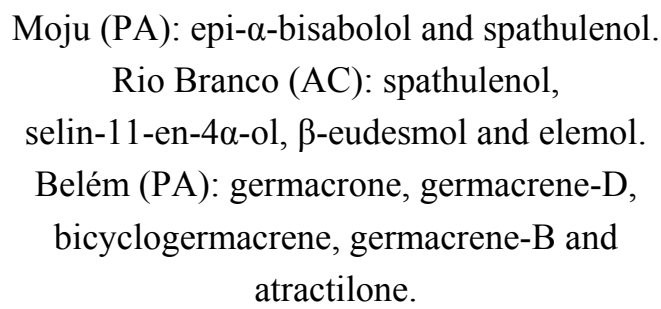 \\
\hline
\end{tabular}

Torres et al. [18] evaluated the chemical composition of the volatile components present in the bark of Capsicodendron dinisii Schwancke, botanical synonym for C. dinisii, and verified the presence of 23 compounds ( $90 \%$ of the total oil composition), as $86.8 \%$ monoterpenes and limonene was found as the majority compound (68.5\%). Similar results were observed in this study as to the class of compounds present in the highest percentage since $76.20 \%$ monoterpenes was found in the oil under study, but it was different regarding the majority component, limonene, that in the present work presented a percentage of $1.54 \%$. 
One can see how in the present study, the other studies described that evaluated the chemical composition of the essential oils of species present in four of the five genera of the family Canellaceae (Cinnamodendron, Canella, Cinnamosma, Warburgia and Pleodendron), presented, as a common characteristic, that all components are of terpenic origin, being mostly monoterpenes and sesquiterpenes.

Studies by Adams and Zanoni [19] evaluating the chemical composition of the essential oil obtained from wood of Cinnamodendron ekamani, a species of the same family as $C$. dinisii, verified the presence of 1,8-cineole (35.9\%), $\alpha$-humulene (9.1\%), $\beta$-caryophyllene (6.5\%), 4-terpineol (5.0\%), germacrene-D (4.9\%), $\beta$-elemene (4.8\%), $\alpha$-pinene $(3.6 \%)$ and $\alpha$-terpineol $(3.0 \%)$. Subsequently Tucker et al. [20] observed the presence of 1,8-cineole (51.0\%) and sabinene (10.6\%) in the chemical composition of a commercial essential oil from Madagascar, named Mandravasarotra (Cinnamosma fragrans Baill., Canellaceae).

The essential oil of the leaves of Canella winterana (L.) Gaertn. (Canellaceae), from the islands of Abaco (Bahamas), presented a total of 19 compounds (100\% of the total composition), the majority components being myrcene (32.4\%), $\beta$-caryophyllene $(18.8 \%)$ cis- and trans- $\beta$-ocimene $(15.9 \%$ and $14.0 \%$, respectively) [21]. Preliminary analysis of the essential oils of leaves and bark of Pleodendron costaricense indicated that the composition of the essential oils of the two parts of the plant analyzed were very similar, showing high levels of $\beta$-pinene, $\alpha$-pinene, $\beta$-myrcene, $\beta$-thujene and $\beta$-caryophyllene with a lesser amount of linalool. The main difference between the volatile compositions of the two parts of the plant was the content of $\beta$-caryophyllene, which was the second most abundant component in the leaves, but almost absent in the bark [22].

The results obtained for the chemical composition of $S$. guianensis corroborate the results found by Valentini et al. [23], which identified and quantified the majority compounds of the volatile chemicals extracted from leaves of $S$. guianensis in an area of cerrado in Mato Grosso, for twelve months. They found that in relation to the variability of the classes of compounds in question, $70 \%$ of the identified compounds were sesquiterpenes and sesquiterpene hydrocarbons that appeared in the rainy season and dry-rainy season transition, with increased production in February 2008, the same month oil was obtained in the present study.

Antônio et al. [24] found, in the leaves of S. guianensis Panama, curzerene (25.64\%), derivatives their degradation (42.31\%) and myristicin (7.93\%). In the same period, Rebouças [25] studied the essential oil of $S$. guianensis, plants collected in Rio Branco, Acre, and observed that the majority components of the essential oil were $\gamma$-cadinene $(21.8 \%)$, bergamotene $(14.2 \%)$ and $\beta$-caryophyllene (15.1\%).

Subsequently, Montanari [26] noted that in the essential oil of plants collected in the city of Tocantins (MG), two constituents, the monoterpene $\alpha$-terpinolene and the sesquiterpene alcohol $\alpha$-bisabolol, together, accounted for about $80 \%$ of the oil composition throughout the year, results that differ from those found in our work where only the $\alpha$-bisabolol was found, but in smaller quantities.

Essential oils from leaves and fruits of $S$. guianensis collected in the southeastern Brazilian cerrado presented as major constituents in the leaf oil, decanoic acid (46.6\%) and 2-undecanone (31.7\%), in the fruit oil mainly undecanone-2 (32.5\%), $\beta$-pinene (19.6\%) and limonene (13.6\%) were found, results that differ from those found in this present study [27].

The essential oils of $S$. guianensis obtained from plants collected in different places of the Amazon showed differences in their constitution. In the essential oil sample collected in Moju (PA) were the 
majority constituents epi- $\alpha$-bisabolol (25.1\%) and spathulenol (15.7\%), the essential oil sample collected in Rio Branco (AC) presented as majority compounds spathulenol (22.0\%), selin-11-en-4 $\alpha$-ol (19.4\%), $\beta$-eudesmol (10.0\%) and elemol (10.0\%), while in the oil sample collected Belém (PA) the presence was verified of germacrone $(23.2 \%)$, germacrene-D $(10.9 \%)$, bicyclogermacrene $(8.6 \%)$, germacrene-B (8.0\%) and atractilone (31.4\%) as majority compounds [28]. The chemical composition of essential oils evaluated in our study showed similarities with the oil of the plant collected in Belém (PA) regarding the majority presence of germacrene-D and bicyclogermacrene.

Differences in content and chemical composition of essential oils extracted from a species often occur, since the production of secondary metabolites, including essential oils, is strongly influenced by the environment in which the producing organism is inserted, and the factors responsible for such variations are, seasonality, circadian rhythm, age and plant development, as well as the different plant organs, temperature, water availability, nutrients, altitude, atmospheric composition and attack of pathogens and herbivores $[29,30]$.

\subsection{Antioxidant Activity}

By the $\beta$-carotene/linoleic acid method, the essential oils studied showed little antioxidant activity, but did not provide $\mathrm{IC}_{50}$ values $\left(>300 \mu \mathrm{g} \mathrm{mL}^{-1}\right)$ in the concentration ranges tested. Among standards tested, BHT $\left(\mathrm{IC}_{50}>25 \mu \mathrm{g} \mathrm{mL}{ }^{-1}\right)$ was the most efficient, followed by thymol $\left(\mathrm{IC}_{50} 105.82 \mu \mathrm{g} \mathrm{mL}^{-1}\right)$ and ascorbic acid $\left(\mathrm{IC}_{50} 118.15 \mu \mathrm{g} \mathrm{mL}^{-1}\right.$ ), respectively (Table 3 ).

Employing the DPPH technique, antioxidant activity was not observed for the essential oils studied, but among the standards assessed, ascorbic acid $\left(\mathrm{IC}_{50} 44.36 \mu \mathrm{g} \mathrm{mL}{ }^{-1}\right)$ was more efficient than BHT $\left(\mathrm{IC}_{50} 48.84 \mu \mathrm{g} \mathrm{mL}^{-1}\right)$ followed by thymol $\left(\mathrm{IC}_{50}>300.00 \mu \mathrm{g} \mathrm{mL}^{-1}\right.$ ) (Table 3).

Table 3. Antioxidant activity of essential oils of $S$. guianensis and $C$. dinisii and of the standards thymol, BHT and ascorbic acid by the $\beta$-carotene/linoleic acid test and the DPPH radical sequestration method.

\begin{tabular}{ccc}
\hline Methods & $\boldsymbol{\beta}$-carotene/linoleic acid & DPPH \\
\hline Components & $\mathrm{IC}_{50} *\left(\mu \mathrm{gL}^{-1}\right)$ & $\mathrm{IC}_{50}\left(\mu \mathrm{g} \mathrm{mL} \mathrm{m}^{-1}\right)$ \\
C. dinisii & $>300.00$ & $\mathrm{NI} * *$ \\
S. guianensis & $>300.00$ & $\mathrm{NI}$ \\
BHT & $<25.00$ & 48.84 \\
Thymol & 105.82 & $>300.00$ \\
Ascorbic acid & 118.15 & 44.36 \\
\hline
\end{tabular}

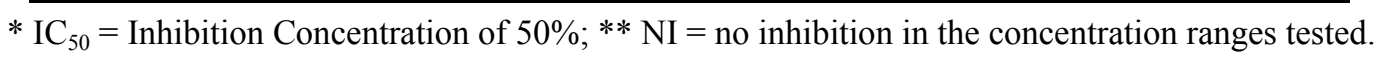

According to the results, it can be said that the essential oils rich in terpenes showed better values for the antioxidant activity in the $\beta$-carotene/linoleic acid system oxidation assay, as the $\beta$-carotene/linoleic acid method can be especially useful for investigations of lipophilic antioxidants and is appropriate for the investigation of antioxidant activity of essential oils. On the other hand, if polar compounds, such as ascorbic acid, were only tested by it, they would be considered weak antioxidants [31]. This explains the lower efficiency of ascorbic acid, compared with thymol. 
According to Ruberto and Baratta [32], in lipid systems, phenolic compounds are effective antioxidants, thus, thymol and carvacrol molecules are indeed responsible for the antioxidant activity of many essential oils that contain them and a scant antioxidant activity is given to monoterpene and sesquiterpene hydrocarbons. Only three monocyclic components, terpinolene, $\alpha$-terpinene and $\gamma$-terpinene, and to a lesser degree, sabinene (a bicyclic), show considerable activity. The presence of these strongly activated methylene group molecules, according to the authors, is probably the reason for this behavior. These results, may explain the low antioxidant activity of essential oils of $C$. dinisii, being composed of $87 \%$ of monoterpene and sesquiterpene hydrocarbons as well as $S$. guianensis, composed of $58.40 \%$ of this group of substances.

According to Mata et al. [33], the absence of antioxidant activity observed for the terpene compounds in the DPPH reduction can be explained by the fact that they are not capable of donating a hydrogen atom and the low solubility provided by them in the reaction medium of the assay, because this test utilizes methanol or ethanol as solvent. Thus, the fact that the essential oils of our study do not show significant antioxidant activity can be explained, since both oils are composed almost entirely of monoterpene and sesquiterpene hydrocarbons. For Viuda-Martos et al. [34], the cited factors can be considered as the main limitation of this assay for measuring the antioxidant activity of lipophilic samples, like many essential oils.

Despite the essential oils tested in this study not showing significant antioxidant activity, many essential oils have shown antioxidant potential. As an example there is the research conducted by Guimarães [35], who investigated the antioxidant activity of essential oils of Lippia sidoides, Alomia fastigiata, Ocotea odorifera, Mikania glauca and Cordia verbenacea, and their majority constituents, by the methods of the $\beta$-carotene/linoleic acid oxidation system, the formation of thiobarbituric acid reactive species (TBARS) and the reduction of the stable DPPH radical, and found that the essential oil of $L$. sidoides showed higher antioxidant activity, presenting the lowest $\mathrm{IC}_{50}$ values in all trials, and the antioxidant activity presented by the essential oil of L. sidoides was attributed to its majority constituent carvacrol, which also showed high antioxidant activity when assessed in isolation. It was also observed that there is influence of the methodology on the antioxidant activity presented by different essential oils and compounds evaluated, demonstrating the importance of the methodology for the determination of activity. Lima et al. [36] observed that the essential oils of Myristica fragrans and Salvia microphylla showed antioxidant potential by the $\beta$-carotene/linoleic acid test, with $\mathrm{IC}_{50}$ values of 976 and $770 \mu \mathrm{g} \mathrm{mL}^{-1}$, respectively.

\section{Conclusions}

We concluded that the main components found in the essential oil of the fresh leaves of $C$. dinisii were $\alpha$-pinene (35.41\%), $\beta$-pinene (17.81\%), sabinene $(12.1 \%)$ and bicyclogermacrene $(7.59 \%)$ and the essential oil of the fresh leaves of $S$. guianensis were identified, $\beta$-myrcene $(13.14 \%)$, germacrene-D (8.68\%) and bicyclogermacrene (16.71\%) and antioxidant activities of the essential oils were evaluated by testing low acid $\beta$-carotene/linoleic and were not evidenced by DPPH to test both oils evaluated. 


\section{Acknowledgments}

To the Conselho Nacional de Desenvolvimento Científico e Tecnológico (CNPq), the Fundação de Apoio à Pesquisa e Extensão de Minas Gerais (FAPEMIG), to CAPES (Coordenação de Aperfeiçoamento de Pessoal de Nível Superior) and to Pest OE/EQB/LA0023/2011, for financial aid and grants provided.

\section{Conflicts of Interest}

The authors declare no conflicts of interest.

\section{References}

1. Simões, C.M.O.; Schenkel, E.P.; Gosmann, G.; Mello, J.C.P.; Mentz, L.A.; Petrovick, P.R. Farmacognosia: da Planta ao medicamento, 6th ed.; UFSC/UFRGS: Porto Alegre, Brazil, 2007; p. 1104.

2. Bandoni, A.L.; Czepak, M.P. Os Recursos Vegetais Aromáticos no Brasil: Seu Aproveitamento Industrial Para a Produção de Aromas e Sabores, 1st ed.; EDUFES: Vitória, Brazil, 2008; pp. 345-367.

3. Bizzo, H.; Hovell, A.M.C.; Rezende, C.M. Óleos essenciais no Brasil: Aspectos gerais, desenvolvimento e perspectivas. Quím. Nova 2009, 32, 588-594.

4. Ramalho, V.C.; Jorge, N. Antioxidantes utilizados em óleos, gorduras e alimentos gordurosos. Quím. Nova 2006, 29, 755-760.

5. Lima, E.S.; Abdalla, D.S.P. Peroxidação lipídica: Mecanismos e avaliação em amostras biológicas. Revista Bras. Cienc. Farm. 2001, 37, 293-303.

6. Oliveira, A.C.; Valentim, I.B.; Goulart, M.O.F.; Silva, C.A.; Bechara, E.J.H.; Trevisan, M.T.S. Fontes vegetais naturais de antioxidantes. Quím. Nova 2009, 32, 689-702.

7. Yunes, R.A.; Cechinel Filho, V. Química de Produtos Naturais, Novos fármacos e a Moderna Farmacognosia, 2nd ed.; Univale Editora: Itajaí, Brasil, 2009; pp. 219-256.

8. Lorenzi, H. Árvores Brasileiras: Manual de Identificação e Cultivo de Plantas Arbóreas do Brasil, 4th ed.; Editora Instituto Plantarum: Nova Odessa, Brazil, 2002; Volume 2, pp. 175-177.

9. Assis, L.; Peixoto, A.L.; de Barros, F. Canellaceae in Lista de Espécies da Flora do Brasil. Jardim Botânico do Rio de Janeiro, 2010; Available online: http://floradobrasil.jbrj.gov.br/jabot/ floradobrasil/FB111724 (accessed on 12 January 2013).

10. Valentini, C.M.A.; Silva, L.E.; Maciel, E.N.; Franceschini, E.; Sousa, P.T., Jr.; Dall'Oglio, E.L.; Coelho, M.F.B. Variação anual do rendimento e composição química dos componentes voláteis da Siparuna guianensis Aublet. Quím. Nova 2010, 33, 1506-1509.

11. Agência Nacional de Vigilância Sanitária. Farmacopeia Brasileira, 5th ed.; Anvisa: Brasília, Brazil, 2010; pp. 198-199.

12. Guimarães, L.G.L.; Cardoso, M.G.; Zacaroni, L.M.; Lima, R.K.; Pimentel, F.A.; Morais, A.R. Influência da luz e da temperatura sobre a oxidação do óleo essencial de capim-limão (Cymbopogon citratus (D.C.) Stapf). Quím. Nova 2008, 31, 1476-1480. 
13. Mendes, M.D.; Lima, A.S.; Trindade, H.; Correia, A.I.D.; Barroso, J.G.; Pedro, L.G.; Figueiredo, A.C. ISSR molecular characterization and leaf volatiles analysis of Pittosporum undulatum Vent. naturalized in the Azores archipelago (Portugal). Ind. Crops Prod. 2011, 33, 710-719.

14. Tepe, B.; Daferera, D.; Sokmen, A.; Sokmen, M.; Polissiou, M. Antimicrobial and antioxidant activities of the essential oil and various extracts of Salvia tomentosa Miller (Lamiaceae). Food Chem. 2005, 90, 333-340.

15. Lopes-Lutz, D.; Alviano, D.S.; Alviano, C.S.; Kolodziejczyk, P.P. Screening of chemical composition, antimicrobial and antioxidant activities of Artemisia essential oils. Phytochemistry 2008, 69, 1732-1738.

16. Wang, W.; Wu, N.; Zu, Y.G.; Fu, Y.J. Antioxidative activity of Rosmarinus officinalis L. essential oil compared to its main components. Food Chem. 2008, 108, 1019-1022.

17. Ferreira, D.F. SISVAR: um Programa para análises e ensino de estatística. Revista Symp. 2008, 6, $36-41$.

18. Torres, E.; Wisniewski, A., Jr.; Simionatto, E.L. Composição química dos componentes voláteis de Capsicodendron dinisii Schwancke (Canellaceae). Quím. Nova 2010, 33, 130-132.

19. Adams, R.P.; Zanoni, T.A. Essential oil of plants from Hispaniola: 1- The volatile wood oil of Cinnamodendron ekamani (Canellaceae). Moscosoa 1989, 5, 154-158.

20. Tucker, A.O.; Maciarello, M.J.; Brown, R.; Griffeth, M. A commercial essential oil of Mandravasarotra (Cinnamosma fragrans Baill., Canellaceae) from Madagascar. J. Essent. Oil Res. 2008, 20, 259-260.

21. Setzer, W.N. Chemical composition of the leaf essential oil of Canella winterana from Abaco Island, Bahamas. J. Essent. Oil Bear. Plants 2007, 10, 475-479.

22. Amiguet, T.V.; Petit, P.; Ta, C.A.; Nuñez, R.; Sánchez-Vindas, P.; Alvarez, L.P.; Smith, M.L.; Arnason, J.T.; Durst, T. Phytochemistry and antifungal properties of the newly discovered tree Pleodendron costaricense. J. Nat. Prod. 2006, 69, 1005-1009.

23. Valentini, C.M.A.; Rodriguez-Ortiz, C.E.; Coelho, M.F.B. Siparuna guianensis Aublet (negramina): uma Revisão. Rev. Bras. Plantas Med. 2010, 12, 96-104.

24. Antonio, T.M.; Waller, G.R.; Mussinan, C.J. Composition of essential oil from the leaves of Siparuna guianensis (Monimiaceae). Chem. Ind. 1984, 14, 514-515.

25. Rebouças, L.M.C. Terpenos de Siparuna guianensis: Aldeídos via Epoxidação de Duplas terminais. Master's Thesis, Universidade Federal do Ceará, Fortaleza, Brazil, 17 February, 1984.

26. Montanari, R.M. Composição Química e Atividades Biológicas dos Óleos Essenciais de Espécies de Anacardiaceae, Siparunaceae e Verbenaceae. Ph.D. Thesis, Universidade Federal de Viçosa, Viçosa, Brazil, 20 December, 2010.

27. Fischer, D.C.H.; Limberger, R.P.; Henriques, A.T.; Moreno, P.R.H. Essential oils from fruits and leaves of Siparuna guianensis (Aubl.) Tulasne from southeastern Brazil. J. Essent. Oil Res. 2005, 17, 101-102.

28. Zoghbi, M.G.B.; Andrade, E.H.A.; Santos, A.S.; Silva, M.H.L.; Maia, J.G.S. Essential oils of Siparuna guianensis Aubl. J. Essent. Oil Res. 1998, 10, 543-546.

29. Gobbo-Neto, L.; Lopes, N.P. Plantas medicinais: Fatores de influência no conteúdo de metabólitos secundários. Quím. Nova 2007, 30, 374-381. 
30. Bakkali, F.; Averbeck, S.; Averbeck, D.; Idaomar, M. Biological effects of essential oils-A review. Food Chem. Toxicol. 2008, 46, 446-475.

31. Kulisic, T.; Radonic, A.; Katalinic, V.; Milos, M. Use of different methods for testing antioxidative activity of oregano essential oil. Food Chem. 2004, 85, 633-640.

32. Ruberto, G.; Baratta, M.T. Antioxidant activity of selected essential oil components in two lipid model systems. Food Chem. 2000, 69,167-174.

33. Mata, A.T.; Proença, C.; Ferreira, A.R.; Serralheiro, M.L.M.; Nogueira, J.M.F.; Araújo, M.E.M. Antioxidant and antiacetylcholinesterase activities of five plants used as portuguese food spices. Food Chem. 2007, 103, 778-786.

34. Viuda-Martos, M.; Navajas, Y.R.; Zapata, E.S.; Fernández-López, J.; Pérez-Álvarez, J.A. Antioxidant activity of essential oils of five spice plants widely used in a Mediterranean diet. Flavour Fragr. J. 2009, 25, 13-19.

35. Guimarães, L.G.L. Óleos Essenciais de Lippia sidoides Cham., Alomia fastigiata (Gardner) Benth, Ocotea odorifera (Vell.) Rohwer, Mikania glauca Mart. e Cordia verbenacea D.C.: Identificação e Quantificação Química, Caracterização das Estruturas Secretoras, Atividades Antioxidante e Antibacteriana. Ph.D. Thesis, Universidade Federal de Lavras, Lavras, Brazil, 11 June, 2010.

36. Lima, R.K.; Cardoso, M.G.; Andrade, M.A.; Guimarães, P.L.; Batista, L.R.; Nelson, D.L. Bactericidal and antioxidant activity of essential oils from Myristica fragrans Houtt and Salvia microphylla H.B.K. J. Am. Oil Chem. Soc. 2012, 89, 523-528.

(C) 2013 by the authors; licensee MDPI, Basel, Switzerland. This article is an open access article distributed under the terms and conditions of the Creative Commons Attribution license (http://creativecommons.org/licenses/by/3.0/). 